\title{
Pedagogia em performance: Uma abordagem do ensino do teatro na escola \\ básica ${ }^{1}$
}

Pedagogy in performance: An approach to theatre teaching in elementary school

Pedro Haddad Martins ${ }^{2}$ 


\section{Resumo}

O presente artigo busca contextualizar, articulando teoria e prática no dia-a-dia da sala de aula, o que seria uma pedagogia em performance - um ensino do teatro que se afirma como prática contemporânea a partir do teatro performativo, e não esquece elementos de sua tradição. Aqui, a performatividade da criança é tomada como material poético para a construção teatral, e efetiva a experiência como prática de elaboração do conhecimento em arte. A pesquisa, realizada com 38 turmas de teatro do sexto ano do ensino básico entre 2012 e 2017, procura, através do relato de experiências, uma possivel resposta para a pergunta: quais abordagens do ensino/ aprendizagem do teatro são potentes hoje?

Palavras-chave: Pedagogia do teatro; ensino do teatro; teatro performativo; performatividade; teatro-educação

\section{Abstract}

This article seeks to contextualize, articulating theory and practice in the classroom, what would be a pedagogy in performance - a theater teaching that affirms itself as contemporary practice from the performative theater, and does not forget elements of its tradition. Here, the performativity of the child is taken as poetic material for theatrical construction, and effectives experience as a practice of elaboration of knowledge in art. The research, conducted from the work with 38 sixth grade theater classes from 2012 to 2017, seeks, through the report of experiences, a possible answer to the question: what approaches to theater teaching/learning are potent today?

Keywords: Theater pedagogy; theater teaching; performative theater; performativity; theater-education

\footnotetext{
1 Este artigo deriva da tese de Doutorado homônima, defendida na Escola de Comunicações e Artes da Universidade de São Paulo (ECA-USP) em 2017, sob orientação da Profa. Dra. Ingrid Dormien Koudela.

2 Prof. Dr. Substituto do curso de Licenciatura em Arte -Teatro da UNESP (Instituto de Artes - Departamento de Artes Cênicas e Fundamentos da Comunicação, IA-DACEFC) e de Teatro da Escola Lourenço Castanho. Integrante fundador da Cia. Elevador de Teatro Panorâmico. pedrom@uol.com.br
} 
Se há, neste artigo, uma tese a ser defendida, ela é, certamente, a própria prática narrada, que serve como base para nossas reflexões e que, após o íntimo diálogo com diversas teorias, volta fortalecida para a sala de aula, de onde saiu primeiramente, mas agora de maneira ainda mais contundente. Portanto, é pelo relato dessa prática que tem início este texto, fugindo do que seria a lógica usual de um artigo, a fim de contextualizar as experiências que impulsionaram a pesquisa, e para que a leitora e o leitor tenham a possibilidade de simular nossas aulas enquanto acompanha nossas reflexões. Segue, portanto, cinco episódios performativos:

\section{Episódio performativo I}

Quatro alunos-atores ${ }^{3}$ de 10 anos de idade, durante a aula de teatro ${ }^{4}$, me pediram para ir ao banheiro. Fiz então um acordo com os quatro, baseado numa experiência narrada por Carmela Soares $(2010)^{5}$. Um deveria ir e voltar o mais rápido possível, outra deveria ir, e depois voltar o mais devagar possível. O terceiro deveria ir e voltar de olhos completamente fechados (para isso ele colocou uma venda). A quarta deveria ir e voltar como um animal de sua escolha. No caso, um cachorro da raça beagle. O primeiro aluno-ator voltou rapidamente. Quando a aula terminou, os outros três ainda não haviam retornado. Uma mal havia saído do banheiro, pois estava andando muito lentamente, como se estivesse andando na lua. O outro, cumprindo a proposta de maneira muito séria, sem conseguir enxergar, havia se perdido. A aluna-atriz que se "transformou" em cachorro estava se divertindo imensamente dentro da secretaria da escola, pedindo carinho para as funcionárias, andando por baixo das mesas e simulando fazer xixi nos pés de todos.

Outros alunos e funcionários da escola tornaram-se espectadores daquela pequena performance, daquele jogo teatral efêmero: um comportamento retirado de seu contexto, que, por apresentar características teatrais, por reconfigurar relações entre movimento, tempo, espaço, ritmo, por obter seu sentido na relação com os espectadores, pode ser caracterizado como objeto estético (Soares, 2010). E, como objeto estético que é, pode ser analisado e reconhecido como produção de teatralidade dentro do ambiente escolar, e proporcionar a possibilidade de que a teatralidade possa também ser reconhecida fora da escola, em outros contextos. Mais do que isto, o envolvimento dos jogadores coloca as estratégias encontradas pelas crianças, para resolver os desafios estéticos propostos, como o centro do processo de significação

\footnotetext{
30 termo escolhido para se referir aos alunos de teatro é aluno-ator. Este termo é adotado por Viola Spolin (2006), e evidencia o caráter formativo (aluno), dentro de um processo teatral (ator), que não tem objetivo de ser profissionalizante ou feito apenas com atores profissionais. Ou seja, nos processos de ensino-aprendizagem em teatro, as crianças estão em formação (aluno) por meio do fazer teatro (ator). 0 termo evidencia a crença de Viola de que todos podem ser atores. Um outro termo, jogador, que vem do francês jouer (jogar, brincar, representar), como em jouer un rôle (representar um papel), e que é usado por diversos autores (inclusive Viola), estará embutido no termo ator deste binômio - que também contém a ideia do ator como participante do teatro como um jogo.

4 As experiências aqui narradas foram realizadas dentro das aulas de teatro no sexto ano do ensino fundamental de uma escola particular na cidade de São Paulo, da qual sou docente. Neste contexto, as aulas de teatro fazem parte da grade curricular obrigatória. A pesquisa inclui processos teatrais - com montagens de peças - com 38 turmas de alunos-atores entre 10 e 11 anos de idade, ocorridos entre 2012 e 2017.

5 Carmela Soares (2010, p. 99-100), em seu livro Pedagogia do jogo teatral, uma poética do efêmero: o ensino do teatro na escola pública, narra uma experiência realizada com alunos da quinta série, durante uma aula de teatro na qual realizava alguns jogos de exploração de ritmos e ações diversas. Quando ela recebeu alguns pedidos dos alunos para sair e beber água, fez um acordo com dois deles: um deveria ir e voltar o mais rápido possível e outro deveria ir e voltar o mais devagar possível. Assim que o primeiro voltou, o segundo nem tinha saído da sala. Quando a aula terminou, o aluno que realizava sua ação bem devagar ainda estava voltando, a meio caminho entre o bebedouro e a sala.
} 
desta pequena, mas potente, manifestação teatral. Aqui, o processo de construção artística de cada aluno-ator é a própria manifestação teatral, que, como linguagem ${ }^{6}$ artística, obedece a certos princípios e códigos específicos:

[...] desenvolver a capacidade de jogo no ensino do teatro significa trabalhar o potencial criativo do aluno segundo princípios e códigos específicos. O objetivo é levar o aluno a reconhecer, durante o próprio ato de jogar, a teatralidade sendo confeccionada, ter consciência dos signos produzidos, conferir ao gesto uma intencionalidade e, ao mesmo tempo, obter um certo distanciamento da ação. Desta maneira, o simples jogar deixa de ter um caráter puramente emocional, catártico, e ganha uma dimensão estética, ao trazer à tona a expressão de uma subjetividade, configurada pela exploração dos meios concretos e específicos à linguagem teatral. (Soares, 2010, p. 71)

\section{Episódio performativo II}

Uma aluna-atriz de 11 anos entra na sala de aula completamente enrolada em papel higiênico, da cabeça aos pés. Anda sem dobrar os joelhos ou os cotovelos. Num sotaque que ela imagina ser egípcio, justifica o seu atraso. Professor, desculpe o meu atraso. Eu estava vindo para a escola hoje de manhã tranquilamente, quando fui raptada por um cientista que me "tele transportou" em sua nave para o Cairo, e me levou para dentro de uma pirâmide, onde estava sendo realizada uma experiência para verificar se é possível mumificar pessoas vivas. Me enfaixou toda. Depois me trouxe de volta. Teoricamente eu teria que ficar enfaixada por uns meses para depois falar para ele se deu certo, se eu não envelheci nadinha durante todo este tempo. Mas eu não sei se vou conseguir, isto aqui incomoda muito! Nem sei se vou conseguir fazer a aula de teatro direito, e imagina só como será para eu tomar banho ou fazer xixi?! Mas de qualquer maneira, gostaria de entrar, mesmo atrasada. O envolvimento da aluna-atriz para a criação de sua própria narrativa ficcional (assim como dos alunos-atores que foram ao banheiro de diversas formas), proporcionou o desenvolvimento de uma pequena cena cheia de energia e vivacidade, empregando suas próprias referências para se comunicar com a plateia (no caso, o professor). Apesar de absurda, surreal, a história foi crível, pois desenvolveu, através de recursos teatrais, uma realidade ficcional, e, por isso, verdadeira enquanto teatro.

O jogo se chama professor bravo7. A regra é simples. Todos os alunos-atores devem ir para fora da sala e fazer uma fila (esta ordem deve ser respeitada até o final do jogo). O professor fica dentro da sala, sentado, de frente para a porta. Cada aluno-ator entra sozinho e fecha a porta. Deve, então, convencer o professor do porquê acabou de chegar atrasado. Se a desculpa for convincente, o aluno-ator pode ficar na sala, sentado e em silêncio, assistindo às tentativas dos outros. Se sua desculpa não for convincente, ele é mandado embora da sala e deve ir para o final da fila, esperar novamente a sua vez de inventar uma outra desculpa. Quando um sai, o próximo

\footnotetext{
6 A linguagem é uma forma de expressão e de comunicação que faz uso de sistemas de signos convencionados, sistemas esses que possuem um determinado conjunto de regras, as quais estabelecem formas de combinar significativa e, mais ou menos, criativamente os símbolos. Sendo meio de expressão, a linguagem deve ser transmissivel e traduzível podendo-se conter e/ou transformar noutra linguagem. (Teixeira, in: Koudela; Almeida Jr, 2015, p. 117)

7 Entrei em contato com este jogo em 1998, quando cursava o segundo semestre de um curso profissionalizante para formação de atores. Apesar da conversa com vários colegas e pesquisa em bibliografia específica, sua origem não foi descoberta. Há 15 anos este jogo faz parte de minhas estratégias de ensino/aprendizagem de teatro.
} 
entra, fecha a porta e inicia sua explicação. O título professor bravo vem do fato de que o professor, também como jogador, deve se mostrar sempre desconfiado, e tentar encontrar incongruências nas desculpas dadas pelos alunos-atores. Quanto mais difícil enganar o professor, mas desafiador o jogo ficará, e maior será a conquista em conseguir entrar na sala.

Aliás, a braveza do professor é elemento disparador e referência do universo que, aos poucos, é criado pelo jogo. Quando os alunos-atores percebem que o professor está jogando de verdade, que realmente assumiu o papel de bravo, e que não facilitará para ninguém, sentem-se seguros para, eles também, jogarem com seriedade, assumirem a qualidade de aluno atrasado, e encarar o desafio de inventar uma desculpa como se fosse algo muito importante. O envolvimento, corporal e mental, é total. A vergonha desaparece e o jogo, pelo envolvimento dos participantes, e pelas circunstâncias criadas, entra no terreno do teatro. Cada aluno-ator apresenta uma pequena cena, primorosa, pois legitimada pelo próprio envolvimento, cada vez que tenta inventar uma desculpa. Aqui, podemos, de maneira exemplar, perceber as estratégias (o que caracterizaremos posteriormente como performatividade) de cada um como elemento criativo. Não existe o apoio em personagens, mas, ao mesmo tempo, o próprio fazer dos alunos-atores, segundo sua própria lógica de resolução do problema, faz com que esta figura seja dotada de características próprias, como se fosse um personagem. Além disso, conseguimos identificar elementos constituintes de uma cena teatral, como definidos por Viola Spolin $(2006)^{8}$ a partir de seu processo pedagógico improvisacional (o Sistema de Jogos Teatrais): o quem? (mesmo que este personagem seja o próprio aluno-ator inserido num contexto teatral); o onde (a sala de aula e/ou um lugar externo, anterior à narrativa, como o Egito, por exemplo); o o quê? (tentar entra na sala de aula); o como? (inventar uma desculpa, convencer o professor/plateia). Uma cena, segundo estas unidades básicas, está posta, como por brincadeira, e estes aspectos podem ser levantados com os alunos-atores em momentos de apreciação coletiva: isso que vocês fizeram era teatro? Na performance dos alunos-atores, por seu envolvimento na resolução do problema, por sua simples presença, e pela circunstância e focos claros do jogo, encontramos, portanto, a síntese de diversos elementos teatrais que fazem desse jogo, teatro.

\section{Episódio performativo III}

Em 2012, quando comecei a dar aula de teatro para o sexto ano, o diretor da unidade fez um pedido muito temido por diversos professores: que tal fazermos uma quadrilha? Pronto. Imediatamente passou pela minha cabeça milhares de questões sobre as quais já havia me debruçado. Estaria eu entrando no tão conhecido lugar do professor de teatro como executor de quadrilha, de autos de natal no final do ano, de pecinha sobre a preservação da natureza ou sobre a poluição da água? Seria eu ob-

8 Na base do Sistema de Jogos Teatrais (theatre games), de Viola Spolin, está uma sistematização empírica da pedagogia teatral desenvolvida por Constantin Stanislavski e de jogos folclóricos tradicionais, levantados pela educadora e autora americana Neva L. Boyd. Alguns elementos de sua pedagogia, portanto, partem de princípios do teatro realista que, como qualquer outra vertente teatral, pode ser incluída em processos do ensino do teatro como um, entre muitos, jeitos de se fazer teatro. 
jeto de uma visão de teatro em que a Arte não é vista como área de conhecimento e está sempre a serviço de algum outro componente curricular? Mas logo percebi meu preconceito e me perguntei: por que não? O espaço estava dado: que fosse usado para o ensino do teatro. Me pareceu desafiadora a ideia de subverter artisticamente estruturas clássicas e reinterpretá-las, num diálogo com o dia a dia dos alunos-atores, aproximando o fazer artístico da realidade contemporânea e por isso, propor uma experiência significativa, pois próxima a eles e, portanto, reconhecível.

Consultei então os alunos-atores que, a princípio, reclamaram, pois acharam que nunca mais teriam que dançar uma quadrilha, pois, afinal, já estavam no sexto ano! Vocês têm dez anos, vocês já têm responsabilidade para inventar o seu próprio jeito de fazer certas coisas. Tudo bem que alguns não gostam de dançar quadrilha, mas o que exatamente vocês gostariam de dançar se pudessem escolher? Na primeira turma, um menino gritou no mesmo instante: Thriller ${ }^{9}$, do Michael Jackson!!!. E logo levantou, acompanhado por outros colegas, para tentar fazer a coreografia do videoclipe. Expus a ideia para as outras turmas que aceitaram sem hesitação. A gente vai poder mesmo dançar Thriller no meio da quadrilha? Não acredito!

As criações artísticas infantis de qualquer época são influenciadas pela arte. Do
mesmo modo, a educação vigente e a concepção de criança interferem como a
arte da criança é trabalhada nas escolas. Hoje reconhecemos na arte de crianças
e jovens a presença de visualidades do entorno próximo e distante. Deste último
por meio da ampliação do acesso a imagens via internet e diferentes mídias; a arte
infantil também sofre influência das tecnologias disponíveis na contemporanei-
dade. (Iavelberg, 2017, p. 66)

Depois de uma contextualização sobre a origem francesa de nossa quadrilha típica brasileira, trazida para cá pelos portugueses, fizemos uma série de improvisações em grupos sobre o que eles entendiam como uma quadrilha "tradicional". Em todas as apresentações um condutor indicava o caminho da roça e gritava os tão conhecidos olha a cobra! (se jogando uns no colo dos outros e se estatelando no chão - um aluno-ator inclusive virou uma cobra gigante) e a ponte quebrou (numa das improvisações todos caíram num rio e se afogaram). Alguns grupos arriscaram fazer um túnel, uma roda ou um caracol, figuras coreográficas típicas da quadrilha. Na hora do casamento o padre bradou: Se alguém tem algo contra o casamento, que fale agora ou cale-se para sempre. Briga geral. Todos mortos no final.

Assistimos então ao videoclipe do Thriller. As improvisações foram refeitas, com a instrução de que os grupos precisavam arranjar uma solução de como inserir a coreografia dentro da narrativa já criada. Todos os grupos pareceram entender que, já que a coreografia no videoclipe era feita por mortos que levantaram de suas tumbas, seria necessário que todos morressem antes de se levantarem como zumbis e começarem a dançar. O que se seguiu foram cenas que começaram como quadrilhas "tradicionais", até encontrar-se um pretexto para que todos morressem, ressuscitassem e dançassem. Fui para casa com todas as sugestões e elaborei um roteiro, além de adaptar a coreografia para passar aos alunos-atores.

9 Thriller é uma faixa pertencente ao álbum homônimo do cantor estadunidense Michael Jackson (1958-2009), lançado em 1982. Em um ano, tornou-se - e continua sendo - o álbum mais vendido de todos os tempos. O videoclipe feito a partir da faixa Thriller, em 1983, e dirigido por John Landis, foi votado como 0 videoclipe pop que mais exerceu influência no mundo. No vídeo, o jovem Michael Jackson quando volta do cinema com uma garota, passa por um cemitério, onde os mortos revivem e tornam-se zumbis, dando início a uma icônica coreografia de mortos-vivos. 
A ideia de começar com uma quadrilha do jeito que os alunos-atores entendem como sendo tradicional, e depois surpreender o público com uma ação inesperada, me pareceu interessante. Os alunos-atores, desse jeito, deixaram a releitura de um clássico evidente (seja a própria quadrilha enquanto tradição, seja a coreografia do Thriller, que também já é clássica). A plateia seria incluída pela identificação com as temáticas apresentadas e pela narrativa, envolvendo espectadores pela surpresa e pelo inesperado, em um jogo inteligente, e por isso divertido, lúdico, de inversão e construção de sentidos e significados a partir do já conhecido.

No roteiro, quatro noivos, irmãos, se casam com quatro noivas, também irmãs. A quadrilha começa com o padre introduzindo as noivas, os noivos e as sogras (uma mãe das noivas e outra, mãe dos noivos). Todos os convidados tomam o caminho da roça até chegar ao local de celebração do casamento. Na fatídica hora em que o padre pronuncia se alguém tem algo contra este casamento, que fale agora ou cale-se para sempre..., uma das noivas resolve que quer trocar de noivo. As irmãs concordam e elas trocam. Mas logo depois outra irmã diz que agora ela é que não está satisfeita. Nova troca. Até que as duas sogras começam a discutir, uma afirmando que esta confusão é culpa dos filhos da outra, que não são bons o suficiente para suas próprias filhas. As duas começam a brigar em câmera lenta, a briga se espalha e, de repente, todos os presentes, inclusive o padre, estão brigando.

Os movimentos da briga, previamente combinados a partir das improvisações em sala, e propostos pelos próprios alunos-atores, incluíam diversos tipos de mortes inusitadas. Um aluno-ator matou o outro apenas enfiando o dedo em seu olho, outro asfixiou o colega obrigando-o a cheirar a sua axila. Uma aluna-atriz matou outra por causa de seu mau hálito. Não faltaram rasteiras, socos, tapas, enforcamentos, cabeças sendo batidas no chão ou no joelho dos outros, beliscões potentes, torcidas de nariz, puxadas de cabelos e petelecos tão fortes que arremessavam o oponente longe. Todos se mataram, portanto. Uns momentos depois, começaram a levantar como zumbis, a música tocava e, depois de dançarem a coreografia, saíram lentamente.

Em conversas com diversas pessoas que assistiram, muitas disseram sentir que as crianças estavam extremamente envolvidas e que a diversão sentida no fazer foi compartilhada com a plateia. A meu ver, isso foi percebido pois o comprometimento com o trabalho deu-se desde a sua criação, dentro de um formato teatral que permitiu com que os alunos-atores trouxessem suas referências. $O$ trabalho era das crianças. Pego emprestado de Peter Slade (1973) a seguinte frase, na qual comenta um aspecto da prática do Drama Infantil:

Ensine-os (os alunos) que eles não fazem este trabalho para mim, você ou qualquer outra pessoa. Eles fazem porque eles amam fazer algo muito bem. É deles, é a coisa que eles fazem. (Slade, 1973, p. 186, grifo nosso) ${ }^{10}$

A plateia, em vez de reduzir a apresentação a uma obra acabada, fez reverberar os resultados e contribuiu para que os alunos-atores se reconhecessem como criadores. Olhando para trás, os alunos-atores começaram a perceber a apresentação

10 Do teach them that they do not do this work for me, you or anyone else. They do it because they love to do a thing well. It is theirs, the thing which they make. (Tradução nossa) 
como momento de comunhão entre atores e plateia. A quadrilha encenada do sexto ano tornou-se uma pequena tradição na escola. Vem sendo feita deste 2012, sempre com narrativas e coreografias diferentes, a partir das referências dos alunos-atores. Em certa escala, o projeto serve como formação de público dentro deste contexto, abrindo os olhos de todos para diversas possibilidades da linguagem teatral, antes deixadas de lado, e colocando em evidência um diálogo claro entre tradição e contemporaneidade.

\section{Episódio performativo IV}

Desde 2013 venho pensando em maneiras de abordar questões próprias a história do teatro a partir da prática dentro da sala de aula. Poderia, claro, dar algumas aulas expositivas sobre determinado assunto e, como modo de inseri-lo como prática teatral, fazer com que estes assuntos fossem temas de improvisações, seguidas de discussão/reflexão. Mas sentia que isto poderia ser menos potente para firmar a experiência como conhecimento, do que atividades onde o aluno-ator - instrumentalizado com elementos da história do teatro - tivesse a liberdade artística de construir sua própria história, de jogar com a história do teatro. Colocar a história em performance. Chegou-se então a um estudo teórico-prático a partir de três diferentes tipos de palco, o palco italiano, o palco elisabetano e a arena grega.

O palco italiano foi estudado a partir de uma visita presencial ao Teatro Municipal de São Paulo. Uma breve contextualização sobre a origem do palco italiano foi dada em aula. Abordou-se seu formato de caixa preta, que favorece a impressão de que o que está sendo encenado dentro dele é mesmo de verdade, e a quarta parede, uma separação entre palco e plateia, que coloca os espectadores como observadores, distanciados da ação que se passa no palco. Outras questões foram guiadas por uma ficha, elaborada especificamente para este estudo (que foi preenchida em vários momentos), e que tem como introdução:

\footnotetext{
Caro(a) aluno(a),

Esta ficha tem como objetivo estudar um pouco da história do teatro pelo contato com três diferentes tipos de palco: o teatro grego (arena ou semi-arena), o palco italiano e o palco elisabetano. As características destes palcos darão elementos para que consigamos entender como o teatro era feito em diferentes épocas.

Para o preenchimento desta ficha, além de nossas aulas de teatro, também visitaremos o Teatro Municipal de São Paulo e assistiremos ao filme Shakespeare apaixonado.

Podemos começar a nossa reflexão em busca da resposta para a seguinte pergunta: Existe diferença no jeito de fazer (e ver) teatro dependendo do espaço e da época onde ocorre a encenação?
}

Especificamente sobre o Teatro Municipal, os alunos-atores foram direcionados a observar alguns aspectos que poderiam ser relacionados ao formato do palco italiano em geral, e outros que pertenciam ao contexto específico desta construção paulistana, como pinturas e esculturas que contam um pouco da origem do teatro - como a escultura de um sátiro, personagem mitológico grego que é bode da cintura para baixo e humano (com chifres) da cintura para cima. O sátiro é considerado 
mitologicamente o primeiro ator da história, já que se disfarçou de Dionísio (o Deus do Teatro e do Vinho), para que pudesse ter privilégios e beber durante uma comemoração. Além disso observamos e conversamos como a organização da sociedade na época foi determinante para a arquitetura do teatro, estabelecendo lugares diferenciados na plateia para diferentes membros da sociedade. Também verificamos elementos técnicos de um palco italiano, como o formato de caixa preta, o espaço da plateia, do palco, o urdimento, o fosso, a coxia, tapadeiras, bambolinas, recursos de iluminação, proscênio, varas de cenário e luz, etc.

O palco elisabetano e o contexto de produção das peças de Shakespeare foram abordados através da exibição do filme Shakespeare apaixonado ${ }^{11}$. O filme mostra, de maneira fictícia, o jovem Shakespeare quando escreveu Romeu e Julieta, pressupondo que a inspiração para a peça veio de um romance que viveu com uma mulher da nobreza. Retrata a dinâmica de produção teatral da época, assim como os costumes culturais, sociais e políticos da Inglaterra Elisabetana. O teatro elisabetano é apresentado com precisão (sua estrutura e o modo como era ocupado por atores e plateia). Por fim, uma aula expositiva curta foi dada sobre a origem do teatro na Grécia e as características de um teatro de arena grego.

Em aula, a partir de todas as informações observadas, anotadas e discutidas, preenchemos em grupo uma tabela que deveria conter as seguintes informações a respeito de cada tipo de palco (italiano, elisabetano, grego): características da construção (do palco e da plateia); elementos técnicos (iluminação, cortinas, coxias...) e jeito de atuar dos atores e/ou atrizes. O jeito de atuar em cada palco, portanto, é fruto do contexto dentro do qual ele foi construído, o que também determina o seu formato.

Entre as conclusões que os alunos-atores chegaram (e que pertencem às características de cada tipo de palco, mas não foram explicitadas pelo professor) : os atores gregos deveriam ter que gritar muito e fazer gestos muito grandes pois o teatro era gigante e a céu aberto (também por isso usavam máscaras que amplificavam suas vozes e caracterizavam seus personagens); no teatro elisabetano os atores sempre tem que falar onde estão, pois não existe espaço para montar um cenário, e se não falarem, ninguém entende onde se passa a peça; no palco italiano, como dá para apagar a luz, a gente pode mudar várias coisas sem o público perceber, enquanto está escuro.

Experimentamos então atuar simulando estar em cada um destes palcos, de maneira a perceber que tipo diferente de atuação poderia surgir a partir de cada contexto histórico. Existe um jeito diferente de se colocar dentro da estrutura elisabetana que é diferente do jeito de se colocar em uma arena, ou em um palco italiano?

Ao final, cada aluno-ator desenha um palco imaginário, que demanda um tipo de atuação e uma relação com a plateia específicas. Os desenhos dos palcos foram compartilhados. Dois ou três palcos foram escolhidos coletivamente para que cenas fossem feitas neles. Para isso os alunos-atores puderam inventar histórias e colocar a plateia onde quisessem, além de usar os praticáveis da sala e a iluminação disponível. Alguns grupos montaram espaços como arenas, onde o público ficava ao redor dos alunos-atores que se apresentavam. Outros apresentaram em diversos outros luga-

11 Shakespeare apaixonado (Shakespeare in love). Direção de Jonh Madden. E.U.A./Inglaterra, 1998. 137min. Vencedor de sete Oscar em 1999, incluindo o de Melhor Filme e Melhor Roteiro Original. 
res da escola. Um grupo propôs um espaço onde o público ficava de costas, e apenas escutava os atores, outro grupo fez a plateia ficar deitada e atuavam andando por cima do público. Um outro grupo propôs um espaço onde o público ficava sentado no centro e os atores ao redor, no que chamaram de teatro-ovo - os atores eram a clara e o público a gema.

\section{Episódio performativo V}

Em 2015, com uma turma de quatorze alunos-atores entre 10 e 11 anos, resolvemos montar uma peça baseada em Odisseia ${ }^{12}$, que narra a viagem de Ulisses de volta à Ítaca, onde era o Rei, após ter vencido a Guerra de Troia, que durou dez anos (sua viagem de volta também teve esta duração). Nesta montagem, todos os alunos-atores ficaram no palco, sentados em cubos no fundo do espaço. Quando faziam uma cena, levantavam e iam um pouco para a frente, para depois retornar ao seu lugar do que poderia ser um ator-espectador. Quase no final da apresentação pública, percebi um cochicho entre os alunos-atores que estavam sentados ao fundo, e um deles levantou correndo, saiu pela coxia e entrou no camarim enquanto outra cena estava acontecendo. O cochicho continuou por um breve momento e, logo depois, os alunos-atores continuaram atentos para quando fosse a hora deles entrarem em cena. Mas o aluno-ator que saiu não voltou e eu sabia que, logo, ele deveria entrar como o velho criado de Ulisses, Eumeu, que o receberia assim que chegasse em Ítaca de sua viagem.

Imediatamente saí da cabine de som/luz, onde assistia ao espetáculo, dei a volta e encontrei o aluno-ator no camarim, sentado, calmamente tomando água. Perguntei se estava tudo bem. Eu fiquei um pouco enjoado, ele respondeu, acho que estava muito nervoso, mas não consegui vomitar, agora já estou um pouco melhor, mas acho que não consigo voltar para terminar a peça. Eu fiquei imaginando o que poderia fazer, se eu deveria parar a peça, se eu deveria entrar e fazer o seu papel, imaginei como os outros alunos-atores deveriam estar nervosos; pensei em várias soluções para resolver a questão, mas antes que eu falasse mais alguma coisa ele me disse: não se preocupe, já combinamos a minha substituição lá no palco, vai dar tudo certo, eu volto no agradecimento. E deu certo. Me senti completamente inútil e, por isso, fiquei feliz da vida. Voltei para assistir à peça absolutamente seguro de que os alunos-atores resolveriam da melhor maneira possível: a maneira deles.

Todos os alunos-atores que estavam em cena sabiam a história inteira, haviam-na criado juntos e tinham domínio sobre o trabalho. O processo incluiu o estudo da história, a improvisação de diversos trechos, a elaboração coletiva de um roteiro com as ideias encenadas em sala por todos, a divisão de personagens a partir das vontades de cada aluno-ator (e da sensibilidade do professor em perceber qual o desafio que seria potente para cada um) e os ensaios. Não há texto para ser decorado, a apropriação da narrativa se dá através de sua própria encenação, diversas vezes, dentro da sala. O roteiro, que não é definitivo, incorpora, até mesmo no dia da apresentação, as ideias dos alunos-atores, respeitando a narrativa da história escolhida para ser contada.

12 Poema épico grego atribuído a Homero, de tradição oral, que teve sua primeira versão escrita por volta de VIII a.C. 
Desse modo, eles se avisaram em cena que o colega estava passando mal. Um aluno-ator se prontificou em substituí-lo e todos foram sendo avisados. Eles resolveram sozinhos. Ninguém da plateia percebeu absolutamente nada. E, como avisado para mim, o aluno-ator voltou no agradecimento e todos receberam juntos os aplausos.

Mas, para que a criança possa exercer sua presença, para que possa libertar-se nas encenações, colocando-se como autora do próprio trabalho, ela deve ter segurança e estruturas que permitam isto, já que,

A naturalidade somente não significa uma comunicação interessante, do palco para a plateia. Assim, temos dois problemas entrelaçados: primeiro, libertar a vitalidade e beleza individual da criança; depois, reestruturar essa naturalidade a fim de preencher as necessidades da forma de arte. (Spolin, 2006, p. 255)

Não pregamos aqui, portanto, uma liberdade completa e absoluta, condição que poderia colocar a criança em um terreno movediço e assustador, convertendo-se em insegurança e ausência de foco, além de abolir importantes questões da linguagem teatral. As regras aqui, os combinados, os acordos tácitos comuns ao universo teatral, as técnicas, fazem parte do teatro como área de conhecimento, e dão segurança para que o aluno-ator se coloque em performance.

O objetivo das apresentações nos parece, então, em primeiro lugar, de fazer com que os alunos-atores tenham a experiência de se reconhecer como artistas no contato com o público, em um jogo lúdico de comunicação que estende para o palco o processo vivenciado em sala de aula. Como em um jogo, as encenações comportam o improviso e o erro, que são incorporados como elementos de linguagem, quando as crianças são encaradas por sua própria criancice: aqui o comportamento do aluno-ator é digno de significação artística. Ou seja, a própria condição de ser uma criança, já é mais forte do que qualquer outro mecanismo de significação que esteja presente na encenação.

Aqui as encenações acontecem de passagem, por descuido, se poderia dizer, quase como uma travessura das crianças, que interrompem desta maneira o estudo que, fundamentalmente, jamais é concluído. (Benjamin, 2009, p. 114)

Enfatizamos o caráter de passagem das encenações, que são apenas mais uma etapa do processo, interrompendo o estudo - que jamais é concluído -, no sentido de abrir um espaço no qual as crianças são soberanas de sua criação, sem a interferência direta do professor, mesmo que seja apenas por alguns momentos. Um espaço que efetiva a brincadeira, a travessura, como arte, promovendo um sentimento de responsabilidade e de autonomia criativa para com o próprio trabalho.

Nunca esquecemos, durante uma encenação, que é uma criança, e não Hamlet, que está em nossa frente. E queremos saber como aquele aluno-ator resolverá os desafios do palco - como falará ser ou não ser?, como se fingirá de louco, como usará do teatro dentro do teatro para explodir a consciência do rei -, a partir de sua condição de criança, e não exatamente a partir do personagem. A atuação está justamente no espaço entre o aluno-ator e o personagem, que nos deixa entrever a lógica da criança em resolver os problemas cênicos. Sem este espaço para que o aluno-ator exerça sua condição de criança, as encenações carecem de vivacidade. O jogo com 
o público então se dá de maneira protocolar e, nesta relação, a criança não percebe a potência de sua experiência artística.

Nesta montagem de Odisseia - assim como em montagens baseadas em textos de Molière, Brecht, Shakespeare, Ariano Suassuna, Ricardo Azevedo -, muitas das ideias experimentadas cenicamente dentro da sala entram como parte da encenação. As ideias são dadas, portanto, a partir da elaboração de improvisações e posteriormente discutidas e verificadas, coletivamente, se funcionam na prática. Um aluno-ator pode, portanto, propor uma ideia que não será ele que necessariamente fará na montagem. Antes de chegar em Ítaca, vindo de Tróia, Ulisses para, com seus marinheiros, em muitas ilhas. Um dos grupos, com cinco alunos-atores, propôs a seguinte cena, que entrou na montagem: Ulisses, aqui interpretado por uma aluna-atriz (que não seria a mesma a interpretá-lo na montagem), acorda depois de uma tempestade em uma praia desconhecida e percebe que só restaram ele e um marinheiro. O marinheiro olha ao redor e fala que a ilha não estava no mapa. Ulisses então olha em seu GPS e descobre que, misteriosamente, eles foram parar na llha de Páscoa, no Oceano Pacífico! Enquanto estão caminhando, encontram um coelhinho muito fofinho comendo capim. Depois outros dois coelhinhos chegam. O marinheiro não se contém e resolve fazer carinho em um dos coelhinhos, que, rapidamente devora seu braço. O aluno-ator então colocou seu braço para trás e gritou para Ulisses: Esse coelho comeu o meu braço! Ulisses não acredita e fala que o marinheiro deve estar delirando, que o coelhinho é muito fofinho. $O$ coelhinho então devora o outro braço do marinheiro, depois uma perna, depois a outra e então todos os coelhinhos avançam nele e começam a devorá-lo. Quando Ulisses percebe o que aconteceu, os coelhinhos começam a tentar devorá-lo também. Mas Ulisses consegue matar todos dando golpes de sumô, e termina a cena reclamando que acabou ficando sem nenhum ovo de páscoa.

\section{Pedagogia em Performance}

As práticas narradas exemplificam alguns elementos de uma abordagem do ensino do teatro que se propõe em diálogo com o contexto teatral contemporâneo, incluindo elementos de sua tradição e história (que definem o teatro como área de conhecimento). Uma experiência significativa para o jovem, que inclui a intima relação entre a condição de ser da criança, aliada aos mecanismos de construção da linguagem teatral, de maneira potente e lúdica. Ludicidade proporcionada pelo reconhecimento da capacidade de cada um de construção de sentidos poéticos através da arte. Esse teatro experienciado será lembrado pelos alunos-atores por muito tempo, atualizado constantemente como uma memória feliz. Isso é criação de cultura teatral.

O que queremos é ensinar teatro fazendo teatro. Esse nosso desejo se mostra múltiplo, pois, tão diversas quanto as abordagens e práticas dentro do contexto do ensino do teatro, também são as vertentes teatrais praticadas hoje. Não podemos desvincular o ensino do teatro do teatro que se faz fora da sala. Pois entendemos que nossa função é dar elementos para que os alunos-atores se reconheçam capazes de fazer e ver teatro, de identificar os mecanismos de construção poética das manifes- 
tações teatrais, de tornar-se espectador, de eventualmente tornar-se ator, e de, pelo menos, e mais importante, ter a oportunidade de passar por uma experiência teatral.

Então como inserir praticamente questões do teatro contemporâneo na sala de aula? Mais do que isso, como se daria a construção de uma pedagogia em performance, de formato contemporâneo e conteúdo teatral? A partir dos episódios performativos narrados, em diálogo com diversos autores, sem separação entre práxis pedagógica e teoria, entre forma e conteúdo, caminhamos em direção à resposta para esta pergunta, evidenciando uma correspondência entre apreender teatro e fazer teatro.

A interpretação de uma narrativa popular tradicional (seja a quadrilha encenada ou a montagem de Odisseia ou Hamlet) envolve, dentro do acontecimento teatral, a relação entre diversas outras linguagens, entre elas a dança, a música, mídia digitais (internet), o videoclipe, além das próprias manifestações de tradições populares brasileiras ou da cultura pop. Esta releitura, e a abertura para outras linguagens/referências, incluindo uma clara questão metalinguística - já que a própria narrativa é tema para sua desconstrução e reconstrução ou, em outras palavras: a prática dos jogos é a própria experiência estética -, inserem estas práticas dentro de alguns paradigmas do que entendemos aqui por teatro contemporâneo. O ensino do teatro na educação básica flerta, portanto, com modos atuais de diversos processos teatrais. Por esta percepção, podemos nos perguntar se existe uma fronteira delimitada entre a cena contemporânea e os episódios performativos dentro do ensino do teatro na escola básica. Mas o que entendemos aqui como cena contemporânea?

Privilegiamos uma visão em que o teatro contemporâneo se apresenta, em muitos aspectos, como portador de elementos antes restritos ao terreno da pedagogia do teatro - como o foco no processo de criação (e sua sistematização), na experiência do intérprete, na relação entre os membros de um coletivo, e na recusa do ilusionismo, revelando os mecanismos de tessitura de uma obra -, algumas vezes fazendo com que teatro e pedagogia do teatro se correspondam, se interseccionem.

A partir de uma ligação (aditiva) ou relação (recíproca) obtemos assim uma troca entre teatro e pedagogia do teatro que leva a uma correspondência. Frente a uma crescente teatralização da pedagogia do teatro e a uma pedagogização do teatro torna-se cada vez mais difícil separar estas áreas na medida em que diferenciações (como grupo alvo e qualificação profissional dos participantes), modos de trabalho e métodos (no sentido de uma práxis pedagógico-teatral) são crescentemente perdidos (Vassen, 2014, p. 13).

Encarar o teatro contemporâneo por seus aspectos pedagógicos escancara os processos de criação, fornecendo elementos para que possam ser sistematizados, decupados e, assim, praticados dentro da sala de aula (e em diversos outros contextos), relacionando prática artística com prática de ensino em arte.

Parece-nos potente, portanto, caracterizar o teatro contemporâneo a partir da definição de Josette Féral de teatro performativo, que define o teatro que se faz hoje:

Esse teatro, que chamarei de teatro performativo, existe em todos os palcos, mas foi definido como teatro pós-dramático a partir do livro de Hans-Thies Lehman, publicado em 2005, ou como teatro pós-moderno. Gostaria de lembrar aqui que seria mais justo chamar este teatro de 'performativo', pois a noção de performatividade está no centro de seu funcionamento (Féral, 2008, p. 197). 
Adotar o ponto de vista de Féral torna a caracterização do teatro contemporâneo hoje mais aberta e inclusiva, pois não o enquadra unicamente nas teorias do pós-dramático ${ }^{13}$ ou do pós-moderno, unindo essas definições a partir da questão da performatividade - que traz em si características relacionadas à pedagogia do teatro e, portanto, em diversos aspectos, ao ensino do teatro na escola.

[...] se há uma arte que se beneficiou das aquisições da performance, é certamente o teatro, dado que ele adotou alguns dos elementos fundadores que abalaram o gênero (transformação do ator em performer, descrição dos acontecimentos da ação cênica em detrimento da representação ou de um jogo de ilusão, espetáculo centrado na imagem e na ação e não mais sobre o texto, apelo a uma receptividade do espectador de natureza essencialmente especular ou aos modos das percepções próprias da tecnologia...). Todos esses elementos, que inscrevem uma performatividade cênica, hoje tornada frequente na maior parte das cenas teatrais do ocidente (Estados Unidos, Países-Baixos, Bélgica, Alemanha, Itália, Reino Unido em particular), constituem as características daquilo a que gostaria de chamar de "teatro performativo" (Féral, 2008, p. 198).

Segundo Féral, as questões da performance, que influenciaram o teatro contemporâneo, atribuindo-lhe algumas de suas principais características, estão divididas em dois eixos principais, em duas visões da performance através das quais podemos pensar o teatro hoje, e as artes em geral. $O$ primeiro se refere à performance concebida como forma artística, a arte da performance (performance art) herdada dos movimentos artísticos de vanguarda do século XX. O segundo se refere à performance concebida como ferramenta teórica de conceituação do fenômeno artístico, herdada de uma visão antropológica e intercultural da qual Richard Schechner é o maior difusor, dentro da corrente americana dos estudos performativos (performance studies). A autora deixa claro que seu objetivo não é favorecer nenhuma dessas duas visões.

O movimento artístico denominado de arte da performance acabou por se consolidar, entre os anos 1970 e 1980, como o mais teatral dos movimentos que se originaram a partir do Futurismo no início do século XX, passando pelo Dadaísmo e Surrealismo e por outras formas de Live Art, como a Body Art e, em outras instâncias, o Happening. "[...] a arte da performance é o resultado final de uma longa batalha para liberar as artes do ilusionismo e do artificialismo" (Glusberg, 2009, p. 46) e coloca este movimento dentro dos mesmos objetivos do pós-dramático e do pós-moderno, que vão contra os modos de produção artística vigentes até então, fazendo com que o teatro performativo - que inclui estas duas vertentes - tenha também uma característica inovadora.

Quando falamos em teatro performativo a partir do viés estético (de construção formal) proposto pela arte da performance, privilegiamos quatro características principais: o hibridismo da linguagem, que incorpora técnicas de várias formas de

13 Conceito estabelecido por Hans-Thies Lehmann a partir da publicação do livro Teatro pós-dramático (lançado em 1999 na Alemanha, e publicado no Brasil em 2007). Sérgio de Carvalho, na apresentação da edição brasileira, começa escrevendo que "Teatro pós-dramático parte da hipótese de que a partir dos anos 1970 ocorreu uma profunda ruptura no modo de pensar e fazer teatro. Algo que já estava anunciado pelas vanguardas modernistas do começo do século XX - a valorização da autonomia da cena e a recusa a qualquer tipo de textocentrismo - desenvolve-se mais radicalmente, a ponto de assumir um sentido modelar como contraponto da arte ao processo de totalização da indústria cultural." Lehmann aponta a entrada do teatro no século da experimentação "quando a cena passa a refletir sobre suas próprias possibilidades expressivas". (Fernandes, 2008, p. 15) 
arte, valorizando cada uma delas por suas características e em conjunto; o sistema de representação do intérprete e a elaboração da obra como tema e objetivo da performance; a comunicação e relação de coparticipação do público, afastando o processo de um mero exercício de auto expressão (privilegiando a questão aberta da obra, que será finalizada com a participação do espectador como decodificador); a desarticulação de formas teatrais clássicas. Aqui fica claro o viés pedagógico que o teatro contemporâneo, por estas características, traz em seu cerne, já que ele "é afirmado mais enquanto processo do que como resultado acabado, mais como ação e produção em curso do que como produto" (Pupo, 2008, p. 225), corroborando a ideia de que o teatro performativo tem como base características antes restritas ao terreno da pedagogia do teatro e, por tabela, ao ensino do teatro. Se transpostas para a sala de aula, estas características - pedagógicas em sua essência -, podem fornecer elementos potentes para que os alunos-atores compreendam o seu próprio fazer.

O desenvolvimento da quadrilha junina, por exemplo, fornece-nos elementos para pensar em maneiras práticas de dialogar com as características apontadas aqui do teatro performativo, e exemplifica questões da pedagogia do teatro que podem ser levadas para a sala de aula. O próprio tema da encenação, sendo a releitura de uma quadrilha clássica, já nos coloca no terreno do contemporâneo no sentido de desarticular formas tradicionais de manifestações artísticas. Esta desarticulação tem como objetivo a compreensão pelos alunos-atores dos sistemas de significação da linguagem teatral. Antes entendemos estes mecanismos para depois desconstruí-los. A reconstrução, neste caso, instrumentaliza os alunos-atores para que, conhecedores destes mecanismos, sejam capazes de compor esteticamente o seu fazer e entender criticamente as formas de arte que estão lá fora. O contato com elementos de diversas outras linguagens reflete a multiplicidade de meios artísticos (e tecnológicos) aos quais os alunos-atores estão expostos hoje, e reflete o modo de percepção de mundo que eles têm.

Além disso, no contato com a plateia, a quadrilha (e todos os outros episódios performativos narrados aqui) deixa evidente a elaboração da obra pelos alunos-atores, colocando em foco a participação efetiva deles na criação. O público identifica características próprias do universo das crianças em diálogo com elementos da tradição, reelaboradas dentro da linguagem e potencializadoras da comunicação do fenômeno teatral e da narrativa construída. As vontades dos alunos-atores são formalizadas por meio da arte e ganham contornos estéticos, sem abdicar da alegria e da ludicidade presentes durante o processo, mas afastando a experiência de um mero exercício de auto expressão. Questões que ficam evidentes no jogo do professor bravo e no desafio proposto quando os alunos-atores pediram para ir ao banheiro. 0 público então participa da encenação como jogador e entra como participante da brincadeira proposta, surpreendendo-se, e legitimando cada conquista evidenciada por meio da apresentação. Aliás, o prazer em jogar é percebido como elemento significativo da encenação, fazendo parte do que já mencionamos como sistemas de representação do intérprete.

Não privilegiamos aqui qualquer jogo de ilusão. E nem seria possível. Não se esconde o fato de que são crianças, e não atores profissionais, os protagonistas da obra 
teatral. Esta característica torna-se, inclusive, a mais significativa da obra e, como potência artística, deve ser aproveitada para legitimar a experiência em teatro dos alunos-atores.

Voltando à definição de teatro performativo a partir de Josette Féral, encontramos em sua base também a visão de performance herdada da corrente americana dos estudos performativos, que tem como principal estudioso e divulgador o americano Richard Schechner, que, segundo Féral (2008), deixa claro, em seus questionamentos sobre o que é uma performance, que sua definição se amplia para além do domínio específico da arte.

Schechner ampliava ali a noção para além do domínio artístico para nela incluir todos os domínios da cultura. Em sua abordagem, a performance dizia respeito tanto aos esportes quanto às diversões populares, [tanto] ao jogo [quanto] ao cinema, [tanto] aos ritos dos curandeiros ou de fertilidade [quanto] aos rodeios ou cerimônias religiosas. Em seu sentido mais amplo, a performance era "étnica e intercultural, histórica e a-histórica, estética e ritualística, sociológica e política (Féral, 2008, p. 198).

A abrangência da definição da performance, que inclui todas as manifestações humanas do cotidiano, coloca-nos em um terreno demasiado amplo e requer, aqui, um recorte que potencialize sua relação com nosso objeto de pesquisa: o ensino do teatro na educação básica. Assim, parece-nos interessante focar as questões dos estudos performativos pelas ações do performer, em sua atitude dentro da performance e do teatro performativo e, por meio disso, estabelecer uma correspondência com o processo de nossos alunos-atores.

Performer, quer seja num sentido primeiro "de superar ou ultrapassar os limites de um padrão" ou ainda no [sentido] de "de se engajar num espetáculo, um jogo ou um ritual", implica ao menos em três operações, diz Schechner.

1. ser/estar ("being"), ou seja, se comportar ("to behave");

2. fazer ("doing"). E a atividade de tudo o que existe, dos quarks (subpartículas atômicas, formadoras das menores partes de um átomo) aos seres humanos;

3. mostrar o que faz ("showing doing", ligado à natureza dos comportamentos humanos). Este consiste em dar-se em espetáculo, em mostrar (ou se mostrar). (Féral, 2008, p. 200)

Compreendendo estas operações de modo abrangente, elas estariam presentes tanto em uma pessoa que cozinha para outras, em um jogador de futebol, em um artista profissional, na atitude de um aluno-ator dentro da sala de aula, participando de um jogo, ou de uma improvisação, por exemplo. Por este viés, o próprio fato de que o aluno-ator está dentro de um contexto específico do ensino do teatro enquadraria o seu comportamento fora dos padrões do dia a dia, favorecendo o estabelecimento de um lugar para que ele possa, por meio da arte, lançar um novo olhar sobre estes mesmos padrões. O performer, por seu engajamento em um jogo ou em um espetáculo, tem, inclusive, equivalência precisa com a atitude dos alunos-atores. Schechner, a partir de verbos que indicam ações concretas, e que estão em jogo em qualquer performance, evoca a noção de performatividade. No caso do teatro, o mostrar o que se faz tem no compartilhamento do processo - seja na apresentação de performances, de peças de teatro, de jogos ou improvisações na sala de aula -, um lugar concreto de realização. 
A performatividade, inerente a grande parte dos comportamentos humanos, quando vista dentro do terreno teatral, ou seja, em ambientes que têm o teatro como objetivo, coloca a atitude do performer como central a todo o processo. As atitudes performativas (a performatividade) dos atores (ou dos alunos-atores) - o dar-se em performance -, são encaradas como primordiais no teatro performativo.

É evidente que esse fazer está presente em toda forma teatral que se dá em cena. A diferença aqui - no teatro performativo - vem do fato de que esse 'fazer' se torna primordial e um dos aspectos fundamentais pressupostos na performance. (Féral, 2008, p. 201)

Os alunos-atores, não sofrendo a pressão desnecessária de imitar atores profissionais, têm em seu próprio comportamento performativo, quando inseridos no contexto teatral, a possibilidade de fazer arte, dotando o próprio comportamento de significação estética. Esta abordagem permite um formato de ensino que, como Spolin (2008) expõe, garante um lugar para que os alunos-atores utilizem o seu potencial criativo, o seu colocar-se em performance como material de criação estética.

[...] o nível desinteressante, precoce, frequentemente exibicionista, de muitos desempenhos das crianças não deriva de sua inabilidade para compreender e aprender a arte teatral. Revela uma falta de método de ensino que apresente o material à criança de forma a permitir que ela utilize o seu potencial criativo dentro dessa linguagem. (Spolin, 2008, p. 250)

A eficácia de montagens teatrais como a quadrilha ou a Odisseia, ou de jogos como o professor bravo e a invenção de novos tipos de palco - e quando digo eficácia, falo de uma experiência na qual os alunos-atores se reconheçam como criadores em teatro -, comprova a necessidade de incorporar as referências que as crianças trazem, e não negar o que está lá fora. Eu nego a existência de Michael Jackson, expoente exemplar da cultura pop de massa? Ou brincamos, eu e alunos-atores, com esta referência? Podemos, deste modo, recontextualizar, descontextualizar, parodiar, fragmentar, inverter, refazer, imitar, copiar, reproduzir, interpretar, reler, infinitos materiais poéticos, por meio da prática do teatro. Com a arte criamos novas realidades e lançamos um outro olhar para o que nos cerca. Assim, esses materiais, poetizados dentro do espaço cênico, adquirem novos significados, que estarão presentes em cada aluno-ator como experiência artística concreta.

Privilegiar a performatividade dos alunos-atores é afirmar a potência que todos carregam, independente das referências que trazem, de passar pela experiência artística. Fazer teatro não é reconhecer que a criança é dotada de uma performatividade natural, mas inserir esta performatividade em determinados objetivos teatrais e padrões estéticos que proporcionem uma educação teatral potente.

Assim como no teatro performativo, o teatro feito com crianças na educação básica, quando parte do ponto de vista do espectador, extrapola a questão da narrativa linear, e evidencia a performatividade dos alunos-atores como uma outra narrativa, paralela, uma narrativa teatral autoral. Quando assistimos a uma peça com crianças dentro do ambiente escolar, o próprio fato de serem crianças atuando já é mais forte do que a história que está sendo contada. Queremos acompanhar as habilidades de 
cada uma delas dentro do jogo, seu nível de envolvimento e suas conquistas, considerando que não são atores. A performatividade, deste modo, acaba se constituindo no elemento mais forte dos jogos e da montagem.

O espectador acompanha a resolução dos desafios da cena pelos alunos-atores e fica feliz com as conquistas como se fossem suas. A secretária deixa a aluna-atriz que se passa por cachorro fazer xixi em seu pé. A coordenadora assina uma advertência falsa para que um aluno-ator consiga simular uma boa desculpa do porquê chegou atrasado no jogo do professor bravo. Longe de ser complacente, a plateia compreende o esforço e o envolvimento reais que são necessários para o aluno-ator fazer mostrando.

Importante ressaltar que o teatro performativo, como formato teatral, pertence à história do teatro tanto quanto o teatro medieval, o teatro grego e o teatro do absurdo, por exemplo. Um ensino pelo viés performativo comporta, portanto, pelo seu formato aberto, também as formas tradicionais de teatro, que são desmontadas e remontadas de forma crítica.

Aqui o formato é performativo e o conteúdo teatral. Por meio deste formato, múltiplo, podemos trabalhar diversos conteúdos próprios ao teatro, como a história do teatro, outros gêneros teatrais ou a produção dramatúrgica, de maneira contemporânea, aproximando os processos de ensino/aprendizagem dos processos de percepção do mundo dos jovens de hoje. Estudamos Hamlet e seu contexto de produção. Então, após entendê-lo, mas sem descaracteriza-lo, jogamos com ele de diversas formas, e elaboramos, juntos, uma dramaturgia a partir do original. Nosso espectro entra ao som de Thriller, do Michael Jackson. Os nossos coveiros consultam o público, fazendo uma votação para saber de quem é o crânio de Yorick, o velho bobo da corte. No final, todos se matam em um duelo em câmera lenta, em que as esgrimas são substituídas por sabres de luz. A plateia, participante do jogo proposto, atenta às estratégias encontradas pelas crianças para resolver as questões da cena, legitima o ser criança como o elemento mais importante do fenômeno teatral e os legitima, portanto, como criadores.

\section{Referências}

BENJAMIN, Walter. Reflexões sobre a criança, o brinquedo e a Educação. São Paulo: Editora 34, 2002.

FÉRAL, Josette. Por uma poética da performatividade: o teatro performativo. Sala Preta. Revista do Depto. de Artes Cênicas da ECA-USP, n. 8/2008, 197-210. São Paulo: EDUSP, 2008.

FERNANDES, Silvia. Teatros Pós-Dramáticos. In: GUINSBURG, Jacó; FERNANDES, Silvia (Orgs.). O Pós-Dramático: um conceito operativo? São Paulo: Perspectiva, 2008, p. 11-30.

GLUSBERG, Jorge. A arte da performance. São Paulo: Perspectiva, 2009. 
IAVELBERG, Rosa. Arte/educação modernista e pós-modernista: fluxos na sala de aula. Porto Alegre: penso, 2017.

LEHMANN, Hans-Thies. Teatro pós-dramático. Trad. de Pedro Süssekind. São Paulo: Cosac Naify.

PUPO, Maria Lúcia de Souza Barros. O Pós-Dramático e a Pedagogia teatral. In: GUINSBURG, Jacó e FERNANDES, Silvia (Orgs.). O Pós-Dramático: um conceito operativo? São Paulo: Perspectiva, 2008, p. 221-232.

SCHECHNER, Richard. Performance studies: an introduction. Nova lorque: Routledge, 2002.

SLADE, Peter. Child Drama. Londres: University of London Press, 1973.

SOARES, Carmela. Pedagogia do jogo teatral: uma poética do efêmero. São Paulo: Hucitec, 2010.

SPOLIN, Viola. Improvisação para o teatro. São Paulo: Perspectiva, 2006.

VASSEN, Florian. Teatro \pm pedagogia do teatro: correspondências entre teatro e pedagogia do teatro. A[L]BERTO. Revista da SP Escola de Teatro, n. 7/2014, 11-20. São Paulo: Secretaria da Cultura do Estado de São Paulo, 2014.

Recebido em: 30/07/2019 Aprovado em: 11/10/2019 